\title{
Impact of an Abandoned Mine on Surrounding Soils, Surface Water and Stream Sediment: Case of SOMIAF Gold Mine, Côte d'Ivoire
}

\author{
Kouadio Assemien François Yao, David Salze, Miguel Lopez-Ferber, Théophile Lasm, and Olivier \\ Belcourt
}

\begin{abstract}
The old gold mine of Somiaf in Afema district (Southern of Côte d'Ivoire) ceased operating in 1998 without real site rehabilitation. In 2016, geochemical analyses of the soils, stream sediments and Hydrochemical characterization of waters of the surrounding area were carried out to assess the environmental impact of this mining site.

The chemical analyses of surface water revealed that almost all the studied water are of poor quality based on the water quality index (WQI). On soils and stream sediments samples the chemical analyses showed $\mathrm{Cd}, \mathrm{Pb}$ and As pollution. While soil contamination by $\mathrm{Pb}$ may be due to mining activity as shown in the water case, $\mathrm{Cd}$ and $\mathrm{As}$ seems to be coming from agricultural activities due to the widespread contamination. This study allowed us to get an overall view of the state of the environment after the end of the mining activity with the focus on the state of the quality of water consumed by the populations. A more detailed study must be carried out in order to accurately characterize the origin of the metal pollution in the waters.
\end{abstract}

Index Terms-Mining, WQI, metal contamination, Côte d'Ivoire.

\section{INTRODUCTION}

Mining operations like most human activities (agriculture, the production of residential and industrial wastes and urban wastewater) result in the discharge of dissolved and particulate metals into surrounding soils, rivers and stream sediment which can have a significant impact on the sustainability of water resources [1]. Mining activities are often regarded as a major source of contaminant metals in environment [1]-[4]. Nowadays the mining sector reputation is founded on past examples of environmental degradation and impact on human health [5]. As a result mining operations are increasingly being challenged by local populations and environmental protection organizations. However extraction of minerals, base and precious metals is essential to everyday life, making up numerous products we all use. They are also vital raw materials in a large number of

Manuscript received May 10, 2017; revised July 2, 2017.

K. A. F. Yao is with the Industrial and Environmental Engineering, École des Mines d'Alès, 6 Avenue de Clavières 30319 Alès, France. He is also with the Earth Sciences and Mineral Resources Department, University Felix Houphouët Boigny, Abidjan, 22 BP 582 Abidjan 22, Côte d'Ivoire (e-mail: kouadio.yao@mines-ales.fr).

D. Salze, L-F. Miguel, and O. Belcourt are with the Industrial and Environmental Engineering Laboratory, École des Mines d'Alès, 6 Avenue de Clavières 30319 Alès, France (e-mail: david.salze@mines-ales.fr, olivier.belcourt @ mines-ales.fr, Miguel.lopez-ferber @ mines-ales.fr).

T. Lasm is with the Earth Sciences and Mineral Resources Department, University Felix Houphouët Boigny, Abidjan, 22 BP 582 Abidjan 22, Côte d'Ivoire (e-mail: theophile_lasm@yahoo.fr). industries, including ceramics, construction, drugs, electronics, glass, automotive and electricity [6]. The mining industry creates also employment and wealth. For these reasons many mining projects have been conducted in recent decades, mainly in African countries.

The SOMIAF (Société des Mines d'Afema) gold mining operations were carried out from 1992 to 1998 in the Afema district, located in the Sud-Comoé Region of Southern Côte d'Ivoire. In 1998 the mine was abandoned without real remediation work. As a result the pits that had been opened are currently flooded by water flowing from the mining area. These waters and others withdrawn in the rivers serve to feed the populations who are not aware of the risk of poisoning incurred. Based on the Hydrochemical of surface water and geochemical (sediment/soil) characterization, the aim of this study is to evaluate (1) the impact of the abandoned mine on surface water resources, sediments and surrounding soils, and (2) the extent of contamination and/or pollution.

\section{MATERIALS AND METHODS}

\section{A. Study Area}

The sector of Afema, located south-Est of Côte d'Ivoire (Fig. 1) is characterised by sub-equatorial climate type which is locally called "climat attiéen". In this region, four seasons of unequal length exist: (a) a great rainy season from April to July, (b) a small dry season from August to September, (c) a small rainy season from October to November and (d) a great dry season from December to March. The temperature varies between $21^{\circ} \mathrm{C}$ and $33^{\circ} \mathrm{C}$ with annual average of $26^{\circ} \mathrm{C}$. The annual pluviometry varies between 1400 and $2500 \mathrm{~mm}$, and during the great rainy season periods of river floods are frequent [7].

From a geological perspective, the Afema sector belongs to the Proterozoic domain of Côte d'Ivoire. The formations encountered are grouped into two main sets: métavulcanites and metasediments. For details on geology of the sector, readers are referred to [7]-[10]. The contact zone of these geological formations represents the shear zone, oriented NE-SW [7].

\section{B. Methods}

To assess the potential pollution of soils, sediment and surface water by the former gold mine in Afema zone, the study is concerned with:

- The geochemical characterization of sediment and surrounding soils of the Somiaf mine area;

- The hydrochemical characterization of surface water 
comprising mine water and other surface waters positioned downstream and upstream of the abandoned mine.

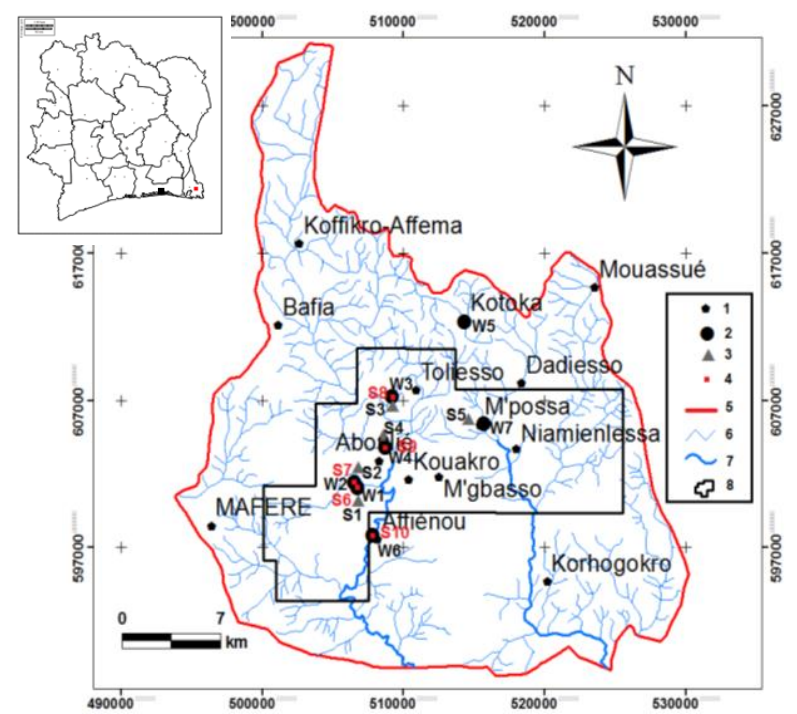

Fig. 1. Location of the study area: 1- Village; 2- Surface water sample; 3Soil samples; 4- Sediment samples; 5- Study area boundary; 6-

Non-perennial watercourses; 7- Main watercourses; 8- Operating license boundary.

\section{Sampling of Soils Sediments and Water}

Samples of soils, sediments and water were collected in February 2016. Five samples of soils referenced S1 to S5 were taken. Three samples were obtained in the immediate area of the mine and two others outside of this area. Samples were taken down to a depth of $10 \mathrm{~cm}$ and packed in polyethylene (PE) bags. Surface water quality study concerned with 7 collection points. One sample was taken in each of the two main pits and one in the former leaching pond. The remaining samples were collected upstream and downstream of Ehania and Noé watercourses (Figure 1). In addition, for each of these surface waters, stream sediment was collected. Field analyses on these waters concerned parameters such as $T, \mathrm{pH}$, Eh and EC turbidity, and major ions. Elements such as $\mathrm{Cd}, \mathrm{As}, \mathrm{Cr}$, and $\mathrm{Pb}$ were also targeted in this study. Samples for metal analyses were acidified with $\mathrm{HNO}_{3}$ while those for ions analyses were not. Each of the two types of samples was collected in PE bottles. For solids samples (soils and stream sediments), analyses concerned $\mathrm{Cd}$ $\mathrm{As}, \mathrm{Cr}$, and $\mathrm{Pb}$. Parameters: $\mathrm{pH}, \mathrm{CE}$, and $\mathrm{Eh}$ were also investigated in soils.

Chemical analyses were carried out at the laboratory of the Centre Ivoirien Anti-Pollution (CIAPOL). In soils and sediments, measurements were performed after sample drying, grinding and digestion with a $\mathrm{HNO}_{3}-\mathrm{HCl}-\mathrm{HF}$ acid mixture according to the methodology proposed by [11]. Quantification was performed on an atomic absorption spectrophotometer (AAS). The surface water samples were analyzed on a Hach DR6000 spectrophotometer.

\section{Assessment of Potential Environmental Risk}

In order to evaluate the quality of soils a significant number of indicators were developed [12]-[14]. In this study the assessment of soils and sediment contamination level was performed by the quantification of the contamination factor (CF) and the pollution load index (PLI).
For each soil/sediment sample and each heavy metal the $\mathrm{CF}$ has been calculated as the ratio between the metal concentrations with its background values as expressed by (1).

$$
C F=C_{\text {heavy metal }} / C_{\text {Background }}
$$

$C F<1$ indicates low contamination; $1<C F<3$ is moderate contamination; $3<C F<6$ is considerable contamination and $C F>6$ is very high contamination [12].

For the entire sampling site, PLI has been determined as the nth root of the product of the $\mathrm{n} \mathrm{CF}$ as indicate in (2):

$$
P L I=\left(C F_{1} \times C F_{2} \times \ldots \times C F_{n}\right)^{1 / n}
$$

The background concentrations of metal (of interest) in soil/sediments come usually from samples taken in the same or close areas, where there was no anthropogenic input. However in the Afema area in addition to mining activity, agricultural activity is strongly practiced. Therefore, it was impossible to find soils not subject to human influence. Accordingly, background values were assumed equal to the element concentrations (in ppm) in the Upper Continental Crust [15].

To estimate the pollution level of the surface water of Afema, World Health Organization (WHO) Standards for waters were adopted. Then the quality index (WQI) was performed for each samples. It is defined as an estimate of water quality based on the influence of several parameters [16]. More information about WQI calculus principles can be found in [16]. The calculation is based on the suitability of given water for human consumption. WQI < 50 indicates excellent quality; $50<\mathrm{WQI}<100$ is good quality; $100<$ $\mathrm{WQI}<200$ poor water; $200<\mathrm{WQI}<300$ is very poor water and WQI $>300$ is water unsuitable for drinking.

\section{RESULTS AND DISCUSSION}

\section{A. Physicochemical Parameters and Metal Concentration}

All soil samples presented an acidic $\mathrm{pH}$ regardless of their origin - in the immediate mining area or outside (Table I). The $\mathrm{pH}$ average value is 5 and indicates a relatively low acidity. These soil samples showed electrical conductivity values between 25.6 and $57.9 \mu \mathrm{s} / \mathrm{cm}$. In contrast, sediment samples showed near-neutral $\mathrm{pH}$ (6.7- 6.9) and EC values of freshwater sediment are almost normal $(\mathrm{CE}<1000 \mu \mathrm{s} / \mathrm{cm})$.

Heavy metal contents show a variation of the average concentrations in soils in the following ascending order:

The studied soils are rich in $\mathrm{Pb}$ with an average of 58.2 $\mathrm{mg} / \mathrm{kg}$. Conversely, they have relatively low concentrations of As with an average of $2.1 \mathrm{mg} / \mathrm{kg}$. In the sediments analyzed, we also observed high concentrations of $\mathrm{Pb}(65$ $\mathrm{mg} / \mathrm{kg})$ followed by $\mathrm{Cd}(20 \mathrm{mg} / \mathrm{kg}), \mathrm{Cr}(5.4 \mathrm{mg} / \mathrm{kg})$ and As which is less abundant with $3.8 \mathrm{mg} / \mathrm{kg}$ average concentration (Fig. 2).

\section{B. Intensity of Heavy Metal Pollution}

The contamination factor (CF) and the pollution load index (PLI) are showed in Table II. CF values for Cd are very high in all samples both in soils and in sediments. For $\mathrm{Pb}$, the 
lower CF value (0.83) was obtained in sample $\mathrm{S} 2$ from soil collected near the pond of the former leaching basin. The same is true (0.90) for the CF obtained in the sediments of this pond.

TABLE I: CADMIUM, LEAD, CHROMIUM, AND ARSENIC CONCENTRATIONS AND PH, EC IN SOILS AND SEDIMENTS OF AFEMA AREA

\begin{tabular}{llllllll}
\hline \hline \multirow{2}{*}{ Samples } & & $\mathrm{pH}$ & $\mathrm{EC}$ & $\mathrm{Cd}$ & $\mathrm{Pb}$ & $\mathrm{Cr}$ & $\mathrm{As}$ \\
\hline \multirow{5}{*}{ Soils } & $\mathrm{S} 1$ & 4.9 & 44.7 & 16.2 & 99.8 & 11.7 & 1.6 \\
& $\mathrm{~S} 2$ & 5.1 & 47.7 & 16.3 & 14.2 & 3.7 & 2.3 \\
& $\mathrm{~S} 3$ & 5.1 & 25.6 & 8.7 & 32.3 & 2.0 & 1.8 \\
& $\mathrm{~S} 4$ & 5.0 & 29.5 & 29.7 & 59.7 & 5.3 & 2.5 \\
& $\mathrm{~S} 5$ & 5.1 & 57.9 & 19.3 & 84.8 & 2.0 & 2.3 \\
& Min & 4.9 & 25.6 & 8.7 & 14.2 & 2.0 & 1.6 \\
& Max & 5.1 & 57.9 & 29.7 & 99.8 & 11.7 & 2.5 \\
& Moy & 5.0 & 41.1 & 18.0 & 58.2 & 4.9 & 2.1 \\
& S6 & 6.8 & 74.7 & 18.3 & 80.1 & 12.5 & 2.0 \\
& S7 & 6.9 & 58.8 & 14.3 & 15.3 & 1.8 & 1.3 \\
& S8 & 6.8 & 35.4 & 23.7 & 98.8 & 6.2 & 4.3 \\
& S9 & 6.7 & 150.3 & 16.2 & 74.7 & 3.8 & 5.1 \\
& S10 & 6.7 & 143.3 & 27.7 & 56.2 & 2.7 & 6.3 \\
& Min & 6.7 & 35.4 & 14.3 & 15.3 & 1.8 & 1.3 \\
& Max & 6.8 & 150.3 & 27.7 & 98.8 & 12.5 & 6.3 \\
& Moy & 6.7 & 92.5 & 20.0 & 65.0 & 5.4 & 3.8 \\
\hline \hline
\end{tabular}

As $<\mathrm{Cr}<\mathrm{Cd}<\mathrm{Pb}$.

Soils S1, S4 and S5 have high values of $\mathrm{CF}$ for $\mathrm{Pb}(3<\mathrm{CF}$ $<6)$. S4 and S5 correspond to the soil sampled a little farther from the immediate area of the old mine. The contamination of these soils by $\mathrm{Pb}$ would suggest a non-mining origin. However, S1 which was taken close to the Anuiri pit reveals a $\mathrm{CF}$ of 5.87. In addition, the $\mathrm{CF}$ values quantified in the sediment from this pit (S6) and those of the Jonction pit (S8) indicate a high $\mathrm{Pb}$ contamination.

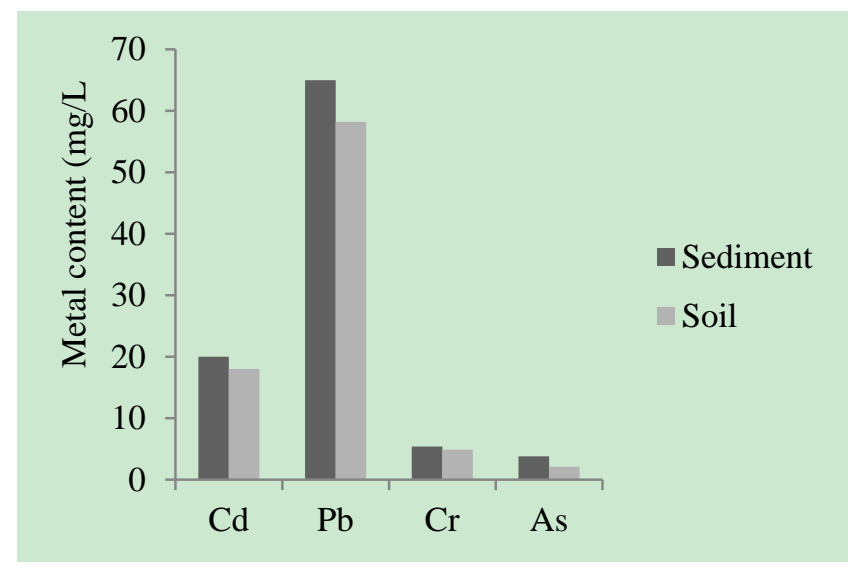

Fig. 2. Average metal content in soils and sediments of Afema area.

Except for S2 (soil close to the leaching basin) and S7 (sediment in the leaching pond), there is a generalized contamination in $\mathrm{Pb}$. In the case of $\mathrm{Cr}$, all $\mathrm{CF}$ values are less than 1 in soils and sediments. For As, CF values indicate low to medium contamination. Soils contamination is lower than sediment contamination.

The pollution load index was calculated to evaluate the degree of contamination. The results of PLI for the selected elements confirm anthropogenic action in the area since all values are $>1$. These results show that soil from the immediate area of mining are relatively less polluted than those collected on sites somewhat distant from this area. For sediments, this variation in pollution seems to be reversed. It is more pronounced in the sediments of the mining pits (S6 and S8) than in the river sediments (S9 and S10). This could be explained by the fact that these reservoirs are larger than rivers and constitute run-off points. This is justified by the low PLI value (1.42) in sediments of the former leaching basin which is very small in extent.

TABLE II: CONTAMINATION FACTOR AND POLLUTION LOAD INDEX IN SOILS AND SEDIMENTS OF AFEMA AREA

\begin{tabular}{|c|c|c|c|c|c|c|}
\hline \multirow{2}{*}{ Samples } & & \multicolumn{4}{|c|}{$\mathrm{CF}$} & \multirow{2}{*}{ PLI } \\
\hline & & $\mathrm{Cd}$ & $\mathrm{Pb}$ & $\mathrm{Cr}$ & As & \\
\hline \multirow{5}{*}{ Soils } & $\mathrm{S} 1$ & 161.67 & 5.87 & 0.33 & 0.79 & 3.96 \\
\hline & $\mathrm{S} 2$ & 163.30 & 0.83 & 0.10 & 1.16 & 1.99 \\
\hline & S3 & 86.67 & 1.90 & 0.06 & 0.91 & 1.73 \\
\hline & $\mathrm{S} 4$ & 296.70 & 3.51 & 0.15 & 1.26 & 3.74 \\
\hline & S5 & 193.33 & 4.99 & 0.06 & 1.15 & 2.85 \\
\hline \multirow{5}{*}{ Sediments } & S6 & 182.50 & 4.71 & 0.36 & 1.02 & 4.21 \\
\hline & S7 & 143.33 & 0.90 & 0.05 & 0.63 & 1.42 \\
\hline & S8 & 236.70 & 5.81 & 0.18 & 2.16 & 4.81 \\
\hline & S9 & 161.70 & 4.39 & 0.11 & 2.57 & 3.76 \\
\hline & S10 & 276.70 & 3.30 & 0.08 & 3.16 & 3.90 \\
\hline \multicolumn{7}{|c|}{ Upper Continental } \\
\hline \multicolumn{2}{|c|}{ Crust (UCC) } & 0.10 & 17 & 35 & 2 & \\
\hline
\end{tabular}

The results obtained also strongly depend on the background values used in the study. The average concentrations in the UCC remain very general and may not correspond to the actual context of studied area. Thus, the values obtained may be either undervalued or overvalued. In the case of an overvaluation this would not constitute a real problem (from a health point of view) because the present results already reveal pollution. However, in the case of undervaluation, this would be detrimental to the health of local populations because the health risk associated with the use of the soil (consumption of plants) and the consumption of water would have been underestimated.

\section{Assessment of Surface Water Quality}

The $\mathrm{pH}$ values of the studied water range from 6.2 to 7.1. Curiously the waters of the old pits (W1, W2 and W3) are closer to neutrality than those of rivers (W4... W7). These values are respectively 7.0, 6.8, 7.1, 6.5, 6.8, 6.2 and 6.4. The EC of these waters is low and oscillates between 19.6 (W3: Junction pit) and 58.85 (W7: Noé River at Kotoka). These low conductivity value reflect low water mineralization as evidenced by major ion concentrations (Fig. 3A). Indeed, the concentrations of major ions are low for all waters. Only bicarbonate ions stand out a bit of the set with higher values in the waters of rivers over the waters from mining pits.

For the trace metal content, analyses do not indicate the presence of $\mathrm{As}, \mathrm{Cr}$, and $\mathrm{Hg}$ in the waters, while $\mathrm{Cd}$ and $\mathrm{CN}$ were found in all waters (except $\mathrm{W} 5$ for $\mathrm{CN}$ ) and $\mathrm{Pb}$ in the Anuiri pit and leach basin (Fig. 3B). The presence of $\mathrm{Pb}$ only in mine waters with high values shows that it's due the mining activities. The obtained values fall far beyond those recommended by WHO $(0.01 \mathrm{mg} / \mathrm{L})$. It is the same to the $\mathrm{CN}$ with the highest values are obtained in these waters but nevertheless remain below the WHO standard $(0.05 \mathrm{mg} / \mathrm{L})$. Furthermore, the $\mathrm{Cd}$ concentrations are all above the tolerance limit $(0.003 \mathrm{mg} / \mathrm{L})$.

Thus the contamination of water by the $\mathrm{Cd}$ could originate either from agricultural activities that use phosphate fertilizers, or from domestic waste. 


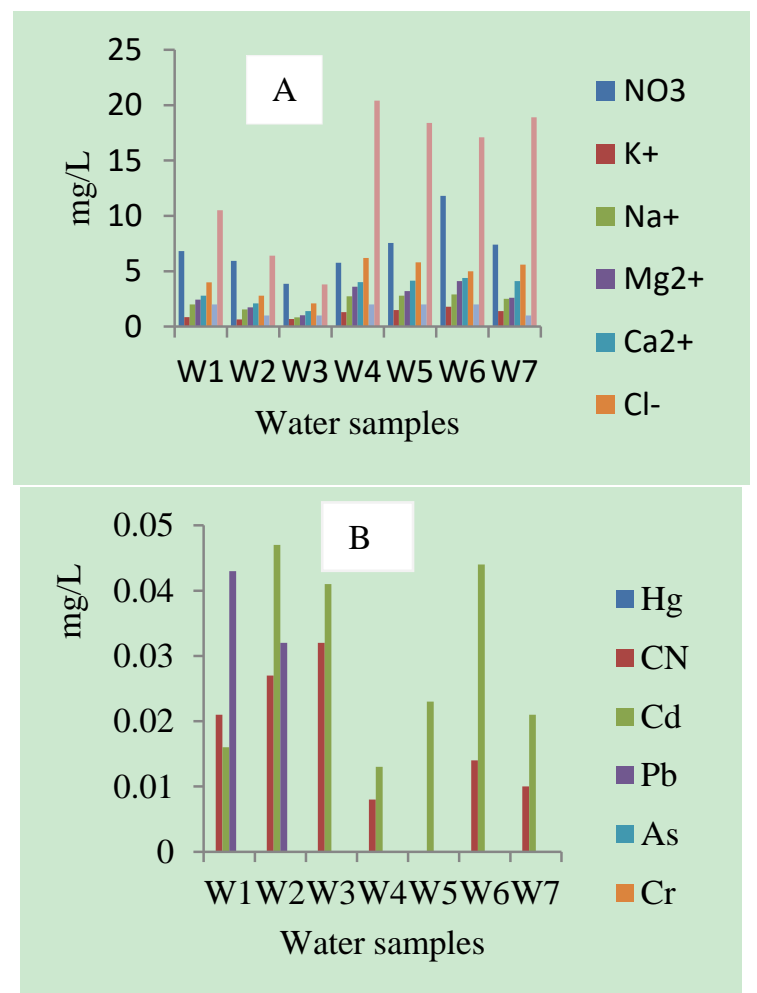

Fig. 3. Chemical composition of water samples: (A) Ions content, (B) Metal content.

Last, the WQI was evaluated to determine water quality. The WQI results show that most of the waters are of poor quality (Fig. 4). Only W4 (Ehania river at Aboulié) has a WQI of less than 100 (i.e. good quality). The highest value is obtained at W2 (leaching basin). Also, the waters of the Ehania and Noé rivers and the Anuiri pit are of poor quality $(100<\mathrm{WQI}<200)$ and yet they are consumed by the populations.

Based on these results, we suggest recommendations to improve environmental conditions and water quality:

- Stopping the consumption of polluted water,

- Stopping or reducing the use of fertilizers in agricultural practices,

- Rehabilitation of the former mine site to prevent the flow of polluted water,

- Involvement of authorities (local/national) for taking a firm decision to fight against pollution.

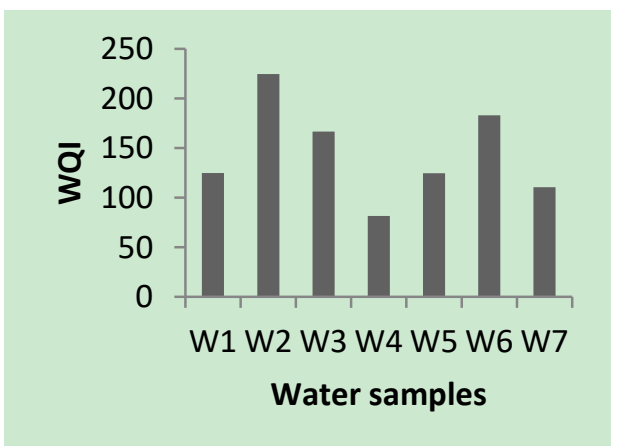

Fig. 4. Water quality index of surface water of Afema area.

\section{CONCLUSION}

After this study, it should be noted that soils and sediment in the study area are contaminated with $\mathrm{Cd}, \mathrm{Pb}$ and As. This contamination is expressed by high contamination factor and PLI values. These results reflect an enrichment of elements of anthropic origin in comparison with average levels in the UCC. $\mathrm{Pb}$ enrichment would be linked to mining activity whereas $\mathrm{Cd}$ and As would be derived from other human activities such as agriculture.

The study also revealed that, like the waters in the old mining works (pits and leach basin), Noé River waters are of poor quality. While it is true that the pollution of the water in the pits is due to the mining, the origin of river pollution is not clear. It could come from agricultural activity or from domestic waste. More detailed studies of water and types of fertilizer used in the area will substantiate these presumptions. In the meantime, it is evident that these waters are not suitable for human consumption. Their consumption without prior treatment exposes the population to health risks.

\section{ACKNOWLEDGMENT}

We would like to thank very sincerely Professor Ahoussi Kouassi Ernest and Professor Yao Koffi Blaise of the Earth Sciences and Mineral Resources Department, University Felix Houphouët Boigny, Abidjan, Côte d'Ivoire for their assistance during the field survey. We would also like to express our gratitude for all reviewers of this work.

\section{REFERENCES}

[1] M. A. Othmani, F. Souissi, E. F. Silva, and A. Coynel, "Geochemistry and potential environmental impact of the mine tailings at Rosh Pinah, southern Namibia," Journal of African Earth Sciences, vol. 111, pp. 231-243, July 2015.

[2] S. Audry, B. Blanc, J. Schäfer, F. Guérin, M. Masson, and S. Robert, "Budgets of $\mathrm{Mn}, \mathrm{Cd}$ and $\mathrm{Cu}$ in the macrotidal Gironde estuary (SW France)," Mar. Chem, vol. 107, pp. 433-448, December 2007.

[3] D. Omanović, I. Piżeta, P.Vukosav, E. Kovács, S. Franćsković-Bilinski, and J. Tamás, "Assessing element distribution and speciation in a stream at abandoned $\mathrm{Pb}-\mathrm{Zn}$ mining site by combining classical, in-situ DGT and modelling approaches," Sci. Total Environ., vol. 511, pp. 423-434, April 2015.

[4] F. F. Monteiro, R. C. Cordeiro, R. E. Santelli, W. Machado, H. Evangelista, L. S. Villar, L. C. A. Viana, and E. D. Bidone, "Sedimentary geochemical record of historical anthropogenic activities affecting Guanabara Bay (Brazil) environmental quality," Environ. Earth Sci., vol. 65, pp. 1661-1669, March 2012.

[5] S. Durucan, A. Korre, and G. Munoz-Melendez, "Mining life cycle modelling: a cradle-to-gate approach to environmental management in the minerals industry," Journal of Cleaner Production, vol. 14, pp. 1057-1070, May 2006.

[6] A. Azapagic, "Developing a framework for sustainable development indicators for the mining and minerals industry," Journal of Cleaner Production, vol. 12, pp. 639- 662, May 2004.

[7] K. E. Assié, "Lode gold mineralization in the Paleoproterozoic (Birimian) volcano-sedimentary sequence of Afema gold district, southeastern Côte d'Ivoire," PhD. dissertation, Technical University of Clausthal, Germany, 2008.

[8] J. P. Milessi et al., "Les minéralisations aurifères de l'Afrique de l'Ouest: leurs relations avec l'évolution lithostructurale au Protérozoique inférieur," Chronique de la Recherche Minière, vol. 497, pp. 3-98 1989.

[9] B. Dibi, "Cartographie des sites potentiels d'implantation des points d'eau dans le département d'Aboisso (Sud-Est de la Côte d'Ivoire) : apport du SIG et de l'analyse multicritère," PhD. dissertation, Dept. Earth Science and Mineral resources, Cocody Univ., Côte d'Ivoire, 2008.

[10] K. A. F. Yao et al., "Mapping of the vulnerability to pollution of aquifers in a mining area: Afema gold mine case (South-eastern Côte d'Ivoire)," International Journal of Innovation and Applied Studies, vol. 17 , no. 2, pp. 682- 697, July 2016.

[11] UNEP/IAEA, "Determination of total lead in marine sediments by flameless atomic absorption spectrophotometry," Reference Methods for Marine Pollution Studies, vol. 34, pp. 1-9, 1985. 
[12] L. Hakånson, "Ecological risk index for aquatic pollution control, A sedimentological approach," Water Res, vol. 14, pp. 975-1001, 1980.

[13] M. T. Guillén et al., "Heavy metals fractionation and multivariate statistical techniques to evaluate the environmental risk in soils of Huelva Township (SW Iberian Peninsula)," J. Geochem. Explor, vol. 119-120, pp. 32- 43, 2012.

[14] M. L. García-Lorenzo, C. Pérez-Sirvent, J. Molina-Ruiz, and M. J. Martínez-Sánchez, "Mobility indices for the assessment of metal contamination in soils affected by old mining activities," Journal of Geochemical Exploration, vol. 147, pp. 117-129, 2014.

[15] K. H. Wedepohl, "The composition of the continental crust," Geochimica et Cosmochimica Acta., pp. 1217-1232, vol. 7, 1995.

[16] C. R. Ramakrishnaiah, C. Sadashivaiah, and G. Ranganna, "Assessment of water quality index for the groundwater in Tumkur Taluk, Karnataka State, India," E-Journal of Chemistry, vol. 6, pp. 523-530, 2009.

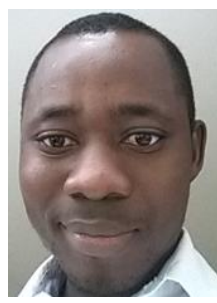

Kouadio Assemien François Yao was born in Tanda, Côte d'Ivoire in 1985 . He received his master degree in the Earth and Mineral Resources Department, University Felix Houphouet Boigny, Abidjan, Côte d'Ivoire, in 2014.

He is currently a doctoral student in the Laboratory of Industrial and Environmental Engineering, École des Mines d'Alès, France. His research interest includes environmental impact assessment and risk assessment especially in mining field.

Mr. Yao is also with the Laboratory of Water Sciences and Environmental Engineering, at the Department of Earth and Mineral Resources, University Felix Houphouet Boigny, Abidjan, Côte d'Ivoire.

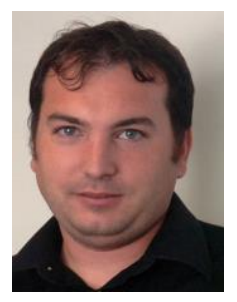

David Salze was born in France. He received his $\mathrm{PhD}$ degree in the Department of Geosciences, University of Nancy -1, France in 2008. After graduation, he joined the Laboratory of Industrial and Environmental Engineering, École des Mines d'Alès, France in 2009. $\mathrm{He}$ is currently assistant professor of mineral extraction engineering at the Industrial and Environmental Engineering, École des Mines d'Alès, France. He participated in several collaborative projects with industrial companies such as AREVA, UNICEM, Réseau d'Excellence Mine et Société.

Dr. Salze present researches include environmental impacts assessment and numerical modelling of the extractive industry.

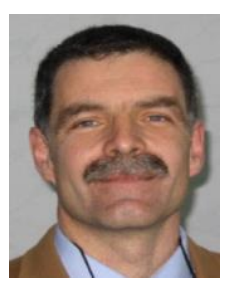

Miguel Lopez-ferber graduated ( $\mathrm{PhD}$ degree) in Pathology and Parasitology. After his PhD, he worked on the reduction of chemical pesticide pollution by developing bio-insecticides at the Laboratory of Industrial and Environmental Engineering, Ecole des mines d'Alès, France. He is currently full professor of environmental engineering at the same Laboratory.

Pr. Lopez-Ferber present research aims to analyse the interactions between organisms or groups and the main drivers conditioning the final response (antagonisms, synergies...), both from the Biological Ecology and from the Industrial Ecology perspectives.

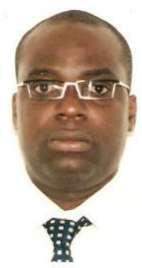

Théophile Lasm was born in Abidjan, Côte d'Ivoire. $\mathrm{He}$ received his $\mathrm{PhD}$ degree in the Department of Geology, Hydrogeology and Geostatistics, University of Poitiers, France in 2000

After his graduation, he worked from 2001 to 2012 as researcher in Laboratory of Water Sciences and Environmental Engineering, University of Cocody (Current University Felix Houphouet-Boigny),

Abidjan, Côte d'Ivoire. His research interest includes quantitative Hydrogeology, Hydrogeology prospecting, Statistics and Geostatistics in hydrogeology, Geology, Groundwater quality and Modeling. He is currently full Professor of Geology, Hydrogeology and Geostastistic at University Felix Houphouet-Boigny, Abidjan, Côte d'Ivoire.

Pr. Lasm is currently the Director of the Laboratory of Water Sciences and Environmental Engineering, University Felix Houphouet-Boigny, Abidjan, Côte d'Ivoire.

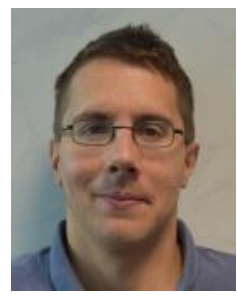

Olivier Belcourt was born in France. He obtained his $\mathrm{PhD}$ degree from University Nancy-1, France in 2009 His competences are geology, mineral resources, water-rock interaction, and environmental impact assessment of extractive industry.

After his $\mathrm{PhD}$, he worked on fluid circulation associated to ore deposits in Luxembourg at G2R Laboratory, Nancy, France. He was Research fellow for GSM, Italcementi Group French subsidiary, on measures to reduce the impact of quarrying on biodiversity.

Dr. Belcourt is currently a research associate at the Industrial and Environment Engineering Laboratory, École des Mines d'Alès, France. His current research fields include environmental impacts assessment and numerical modelling of the extractive industry. 